\title{
PENGARUH ANALISIS RASIO KEUANGAN \\ TERHADAP KINERJA KEUANGAN PERUSAHAAN PT. UNILEVER INDONESIA TBK TAHUN 2017-2019
}

\author{
Dinda Ayu Sieradianto Angelia ${ }^{1}$, Dio Sugiharto ${ }^{2}$, Dytia Nanda Lissetiawan ${ }^{3}$, \\ Egie Regita Cahyani ${ }^{4}$, Erna Khusnul Novita ${ }^{5}$, Fadla Nurfadilah ${ }^{6}$, \\ Feiza Nisa Insani ${ }^{7}$, Agus Joharudin ${ }^{8}$ \\ 1,2,3,4,5,6,7,8 Universitas Islam Negeri Sunan Gunung Djati Bandung \\ Email : dindaayusangelia@gmail.com
}

\begin{abstract}
Abstrak
Untuk mengetahui tingkat kesehatan perusahaan harus dilakukan pengukuran ataupun penilaian kinerja perusahaan. Kinerja adalah prestasi yang dicapai oleh perusahaan dalam suatu periode tertentu yang mencerminkan tingkat kesehatan perusahaan. Tujuannya adalah menemukan kelemahan di dalam kinerja perusahaan yang dapat menyebabkan masalah pada perusahaan. Demikian juga PT. Unilever Tbk yang tentunya ingin mengetahui tingkat kesehatan usahanya dari tahun ke tahun, yaitu dengan cara menilai kinerja manajemen perusahaannya. PT. Unilever Tbk tentunya membutuhkan pengelolaan manajemen yang baik dari permodalan, persediaan barang, dan laba yang akan diperoleh, sehingga perusahaan dapat terhindar dari kurang tepatnya keputusan atau kebijakan yang diambil, serta perusahaan dapat menjalankan kegiatan operasionalnya dengan lebih efisien dan tujuan yang telah ditetapkan dapat tercapai.

Penelitian ini merupakan penelitian kuantitatif karena alat analisis data yang digunakan berasal dari data sekunder laporan keuangan PT Unilever Tbk Pada tahun 2017 - 2019 yang diambil dari www.idx.com. Alat analisis yang digunakan dalam menilai kinerja keuangan perusahaan adalah dengan rasio keuangan, yang terdiri dari likuiditas, solvabilitas, aktivitas, dan profitabilitas. Untuk menilai kinerja keuangan tersebut dengan menggunakan metode time series yaitu dengan cara membandingkan ratio-ratio financial perusahaan dari satu periode ke periode lainnya. Dari rasio likuiditas, solvabilitas, dan profitabilitas setiap tahunnya mengalami peningkatan, hal ini ditunjukan dari penjualan dan laba yang didapatkan perusahaan selalu meningkat, semua kewajiban yang harus ditanggung perusahaan bisa dipenuhi, baik kewajiban lancar maupun tidak lancar, hanya rasio aktivitas yang selalu mengalami penurunan, hal ini terjadi karena kurang efektinya perusahaan dalam mengelola aktiva dan piutang perusahaan.
\end{abstract}

Kata Kunci : Rasio Keuangan; Kinerja Keuangan Perusahaan; Likuiditas; Solvabilitas; Aktivitas; Profitabilitas; PT. Unilever Indonesia Tbk

\section{Abstract}

To determine the level of health company must be measured or assessed company performance. Performance is the achievement achieved by the company in a certain 
period that reflects the level of company health. The aim is to find weaknesses in the company's performance that can cause problems in the company. Likewise, PT. Unilever Tbk, which of course wants to know the level of health of its business from year to year, that is by assessing the performance of the company's management. PT. Unilever Tbk certainly requires good management of capital, inventory, and profits to be obtained, so that the company can avoid inaccurate decisions or policies taken, and the company can run its operations more efficiently and the objectives set can be achieved.

This research is a quantitative study because the data analysis tools used are derived from secondary data from PT Unilever Tbk financial statements. In 2017 - 2019 taken from www.idx.com. The analytical tool used in assessing a company's financial performance is the financial ratios, which consist of liquidity, solvency, activity, and profitability. To assess the financial performance using the time series method by comparing the company's financial ratios from one period to another. From the ratio of liquidity, solvency, and profitability has increased every year, this is shown from the sales and profits obtained by the company is always increasing, all liabilities that must be borne by the company can be fulfilled, both current and non-current liabilities, only the ratio of activity that always decreases, this happens due to the company's lack of effectiveness in managing company assets and receivables.

Keywords : Financial Ratio; Company Financial Performance; Liquidity; Solvency; Activity; Profitability; PT. Unilever Indonesian Tbk

\section{A. PENDAHULUAN}

Kinerja perusahaan adalah suatu usaha formal yang dilaksanakan perusahaan untuk mengevaluasi efisien dan efektivitas dari aktivitas perusahaan yang telah dilaksanakan pada periode waktu tertentu. Menurut Sucipto (2003) pengertian kinerja keuangan adalah penentuan ukuran-ukuran tertentu yang dapat mengukur keberhasilan suatu organisasi atau perusahaan dalam menghasilkan laba. Sedangkan menurut IAI (2007) Kinerja Keuangan adalah kemampuan perusahaan dalam mengelola dan mengendalikan sumberdaya yang dimilikinya. Maka dapat diambil kesimpulan bahwa kinerja keuangan adalah usaha formal yang telah dilakukan oleh perusahaan yang dapat mengukur keberhasilan perusahaan dalam menghasilkan laba, sehingga dapat melihat prospek, pertumbuhan, dan potensi perkembangan baik perusahaan dengan mengandalkan sumber daya yang ada. Suatu perusahaan dapat dikatakan berhasil apabila telah mencapai standar dan tujuan yang telah ditetapkan. Menurut Mas'amah (2019) Kinerja perusahaan bisa dilihat dari laporan keuangan yang baik dan meningkat. Sehingga keadaan dan posisi keuangan akan mengalami perubahan. 
Menurut Azizah, A. (2015) Cara umum yang biasanya digunakan untuk menilai dan mengukur kinerja perusahaan adalah dengan analisis rasio keuangan yang meliputi rasio likuiditas, aktivitas, profitabilitas, dan leverage.

Pengukuran kinerja digunakan perusahaan untuk melakukan perbaikan diatas kegiatan operasionalnya agar dapat bersaing dengan perusahaan lain. Analisis kinerja keuangan merupakan proses pengkajian secara kritis terhadap review data, menghitung, mengukur, menginterprestasi, dan memberi solusi terhadap keuangan perusahaan pada suatu periode tertentu. Kinerja Keuangan dapat dinilai dengan beberapa alat analisis. Berdasarkan tekniknya, analisis keuangan dapat dibedakan menjadi 8 macam, yaitu menurut Jumingan (2006:242):

a. Analisis perbandingan Laporan Keuangan, merupakan teknik analisis dengan cara membandingkan laporan keuangan dua periode atau lebih dengan menunjukkan perubahan, baik dalam jumlah (absolut) maupun dalam persentase (relatif).

b. Analisis Tren (tendensi posisi), merupakan teknik analisis untuk mengetahui tendensi keadaan keuangan apakah menunjukkan kenaikan atau penurunan.

c. Analisis Persentase per Komponen (common size), merupakan teknik analisis untuk mengetahui persentase investasi pada masing-masing aktiva terhadap keseluruhan atau total aktiva maupun utang.

d. Analisis Sumber dan Penggunaan Modal Kerja, merupakan teknik analisis untuk mengetahui besarnya sumber dan penggunaan modal kerja melalui dua periode waktu yang dibandingkan.

e. Analisis Sumber dan Penggunaan Kas, merupakan teknik analisis untuk mengetahui kondisi kas disertai sebab terjadinya perubahan kas pada suatu periode waktu tertentu.

f. Analisis Rasio Keuangan, merupakan teknik analisis keuangan untuk mengetahui hubungan di antara pos tertentu dalam neraca maupun laporan laba rugi baik secara individu maupun secara simultan. Dalam jurnal Yusra, I. (2016), pengertian analisa rasio keuangan menurut James C van Horne dalam buku Kasmir (2010:104) adalah indeks yang menghubungkan dua angka akuntansi dan diperoleh dengan membagi satu angka dengan angka lainnya. Rasio yang umum digunakan adalah rasio likuiditas, solvabilitas dan profitabilitas 
g. Analisis Perubahan Laba Kotor, merupakan teknik analisis untuk mengetahui posisi laba dan sebab-sebab terjadinya perubahan laba.

h. Analisis Break Even, merupakan teknik analisis untuk mengetahui tingkat penjualan yang harus dicapai agar perusahaan tidak mengalami kerugian.

Dalam penelitian kali ini, penulis akan membahas mengenai analisis rasio keuangan terhadap kinerja keuangan perusahaan.

Kasmir (2017) berpendapat bahwa rasio keuangan adalah kegiatan membandingkan angka-angka yang ada terdapat pada laporan keuangan dengan cara membagi satu angka dengan angka lainnya. Menurut Dewa, A. P., \& Sitohang, S. (2015) Perusahaan akan mengevaluasi laporan keuangannya untuk membuat strategi guna mencapai tujuan yang ingin dicapai perusahaan tersebut. Perbandingan tersebut dapat dilakukan antara satu komponen dengan komponen lainnya dalam satu laporan keuangan atau antar komponen yang ada di antara laporan keuangan. Menurut Harahap (2011) definisi rasio keuangan adalah angka yang diperoleh dari hasil perbandingan dari satu pos laporan keuangan dengan pos lainnya yang mempunyai hubungan yang relevan dan signifikan. Definisi rasio keuangan menurut Kariyoto (2017) ialah analisis yang digunakan untuk menunjukkan hubungan antara unsur-unsur dalam laporan keuangan yang diperlukan untuk memeriksa dan membandingkan hubungan-hubungan yang ada pada unitunit informasi dalam laporan keuangan. Menurut Lithfiyah (2019) Pada dasarnya perhitungan rasio-rasio keuangan adalah untuk menilai kinerja keuangan perusahaan di masa lalu, saat ini, dan kemungkinannya di masa depan.

Berdasarkan beberapa pendapat tersebut dapat disimpulkan bahwa rasio keuangan adalah hasil yang diperoleh dari perbandingan antar komponen dalam suatu laporan keuangan yan menunjukkan hubungan yang relatif dan signifikan serta berguna dalam pengambilan keputusan suatu entitas.

Pengelompokan rasio keuangan (Bambang Riyanto, 2001: 331) terbagi ke dalam 4 jenis yaitu rasio-rasio likuiditas, rasio-rasio leverage/solvabilitas, rasio-rasio aktivitas, dan rasio-rasio profitabilitas:

a. Rasio Likuiditas adalah rasio-rasio yang dimaksudkan untuk mengukur likuiditas perusahaan

b. Rasio Leverage Adalah rasio-rasio yang dimaksudkan untuk mengukur sampai berapa jauh aktiva perusahaan dibiayai oleh utang 
c. Rasio-rasio Aktivitas yaitu rasio-rasio yang dimaksudkan untuk mengukur sampai seberapa besar efektivitas perusahaan dalam mengerjakan sumbersumber dayanya

d. Rasio-rasio Profitabilitas yaitu rasio-rasio yang menunjukan hasil akhir dari sejumlah kebijaksanaan dan keputusan-keputusan.

Mengetahui bagaimana kondisi keuangan suatu perusahaan, diperlukan laporan keuangan yang disusun setiap akhir periode tertentu. Laporan keuangan tersebut dibuat oleh manajemen dengan tujuan untuk mempertanggungjawabkan tugas-tugas yang diberikan kepada manajer. Laporan keuangan yang dimaksud berupa neraca dan laporan laba-rugi. Neraca menunjukkan posisi keuangan (aktiva, kewajiban dan ekuitas) perusahaan pada saat tertentu, sedangkan laporan laba rugi menunjukkan kemampuan perusahaan dalam menghasilkan laba yang telah terjadi pada periode tertentu, kemudian laporan keuangan tersebut dianalisis untuk mengetahui secara jelas posisi keuangan dengan menggunakan analisis rasio.

Analisis rasio merupakan teknik untuk mengukur kinerja perusahaan. Analisis rasio ini diharapkan dapat menyingkap hubungan antara pos-pos tertentu, kemudian dapat diambil kesimpulan. Mengingat peranan penting Analisis Rasio Keuangan untuk menilai laju usaha dan perkembangan usaha suatu perusahaan sangatlah besar, maka pengetahuan yang diimbangi kemahiran dalam menganalisis menginterprestasikan datadata dari laporan keuangan sangat bermanfaat bagi perusahaan sebagai acuan dalam pengambilan keputusan yang terkait tentang kebijakan perusahaan untuk memajukan dan mengembangkan usaha.

Sebagai sebuah gambaran kinerja keuangan terbaru dari sebuah perusahaan, PT. Unilever Indonesia Tbk "Perseroan" mengumumkan laporan kinerja keuangan Perseroan untuk kuartal I 2020 (tidak diaudit). Pada kuartal I 2020, Perseroan berhasil mencatat penjualan bersih sebesar Rp11,2 triliun, tumbuh 4,6\% dibandingkan dengan periode yang sama di tahun sebelumnya. Pertumbuhan penjualan ini didorong oleh pertumbuhan penjualan domestik sebesar $4,4 \%$ serta pertumbuhan penjualan ekspor sebesar 9,0\%. Perseroan juga mencatat laba bersih di kuartal I 2020 sebesar Rp1,8 triliun, tumbuh sebesar 6,5\% dibandingkan dengan periode yang sama di 2019.

Hemant Bakshi, Presiden Direktur PT Unilever Indonesia, Tbk menyampaikan bahwa Inovasi menjadi kunci utama Perseroan dalam mempertahankan pertumbuhan positif di kuartal 1 2020, Unilever mencatatkan sebanyak dua puluh satu launch dan 
relaunch yang Unilever lakukan di berbagai segmen. Peluncuran inovasi-inovasi tersebut sejalan dengan strategi Perseroan untuk tetap relevan dan mampu bersaing di masa yang akan datang (future-fit).

\section{B. METODE}

Dalam penelitian ini metode yang penulis gunakan adalah metode deskriptif dengan pendekatan kuantitatif. Metode penelitian deskriptif merupakan suatu metode yang tentunya memiliki tujuan mendeskripsikan atau menggambarkan segala sesuatu yang sedang terjadi saat ini. Yang mana di dalam penelitian ini terdapat upaya untuk mendeskripsikan, mencatat, menganalisis dan juga utnuk menginterpretasikan suatu keadaan yang ada atau terjadi saat ini (Tika, 2006).

Dan penelitian dengan pendekatan kuantitatif merupakan suatu penelitin yang dilakukan dengan cara yang lebih sistematis, terencana, dan terstruktur, selain itu penelitian ini juga berkaitan dengan penggunaan angka.

Dalam penelitian ini, penulis menggunakan jenis data sekunder. Data sekunder merupakan data yang telah dikumpulkan dan dilaporkan oleh intansi atau lembaga terkait di luar dari penelitian sendiri, akan tetapi data tersebut merupakan data yang asli dan berasal dari sumber yang terpercaya (Tika, 2006).

Sumber data yang digunakan dalam penelitian oleh penulis adalah data eskternal yaitu data-data yang diperoleh tidak secara langsung dari sumbernya melainkan dari pihak ketiga atau lembaga-lembaga terkait yang mengolah data tersebut (Erwan Agus Purwanto, 2017).

Data yang digunakan dalam penelitian adalah:

a. Data laporan keuangan tahunan dari tahun 2017 sampai dengan 2019 untuk PT. Unilever Indonesia Tbk yang di dapatkan dari internet melalui situs www.idx.co.id

b. Data kondisi perusahaan terkini dan perkembangannya yang diperoleh dengan mengunduh data di internet melalui web site www.unilever.co.id

\section{Tabel 1}

Standar industri rasio keuangan yang dijadikan alat analisis perhitungan rasio keuangan terhadap kinerja keuangan perusahaan PT. Unilever Indonesia Tbk periode 2017-2019 


\begin{tabular}{|l|l|c|}
\hline \multirow{4}{*}{1} & \multicolumn{1}{|c|}{ Jenis Rasio } & Standar Industri \\
\hline \multirow{4}{*}{1.} & \multicolumn{1}{|c|}{ Rasio Likuiditas } \\
\cline { 2 - 3 } & Current Ratio & $2 \mathrm{kali}$ \\
\cline { 2 - 3 } & Quick Ratio & $1,5 \mathrm{kali}$ \\
\cline { 2 - 3 } & Cash Ratio & $50 \%$ \\
\hline \multirow{4}{*}{2.} & \multicolumn{2}{|c|}{ Rasio Aktivitas Solvabilitas } \\
\cline { 2 - 3 } & Debt to Assets Ratio \\
\cline { 2 - 3 } & Debt to Equity Ratio & $35 \%$ \\
\cline { 2 - 3 } & Long Term Debt to Equity Ratio & $90 \%$ \\
\cline { 2 - 3 } & Time Interest Earned Ratio \\
\hline \multirow{4}{*}{3.} & \multicolumn{2}{|c|}{ Rasio Profitabilitas } \\
\cline { 2 - 3 } & Receivable Turnover & $10 \mathrm{kali}$ \\
\cline { 2 - 3 } & Inventory Turnover & $15 \mathrm{kali}$ \\
\cline { 2 - 3 } & Working Capital Turnover & $20 \mathrm{kali}$ \\
\cline { 2 - 3 } & Fixed Assets Turnover & $5 \mathrm{kali}$ \\
\cline { 2 - 3 } & Total Assets Turnover \\
\hline \multirow{4}{*}{4.} & \multicolumn{2}{|c|}{$20 \%$} \\
\cline { 2 - 3 } & Net Profit Margin & $40 \%$ \\
\cline { 2 - 3 } & Return on Equity & $30 \%$ \\
\cline { 2 - 3 } & Return on Investment & \\
\hline
\end{tabular}

Sumber : Kasmir, 2017

\section{HASIL DAN PEMBAHASAN}

Rasio keuangan yang digunakan dalam mengukut kinerja keuangan PT. Unilever Indonesia Tbk ini adalah Rasio Likuiditas, Rasio Solvabilitas, Rasio Aktivitas, dan Rasio Profitabilitas.

Hasil penelitian ini menguraikan bagaimana menggunakan rumus-rumus rasio dan perbandingan yang berkaitan dengan penelitian yang penulis lakukan. Hasil penelitian ini merupakan hasil dari analisis rasio keuangan PT. Unilever Indonesia Tbk. dengan menggunakan metode analisis horizontal \& menggunakan pendekatan Time Series selama tiga periode waktu dari tahun 2017-2019.

Tabel 2

Hasil Perhitungan Kinerja Keuangan PT. Unilever Indonesia Tbk dengan Analisis Rasio

\begin{tabular}{|c|c|c|c|c|c|}
\hline \multirow{2}{*}{ No. } & \multirow{2}{*}{ Keterangan } & \multicolumn{3}{|c|}{ TAHUN } & \multirow{2}{*}{$\begin{array}{l}\text { Standar } \\
\text { Industri }\end{array}$} \\
\hline & & 2017 & 2018 & 2019 & \\
\hline \multirow{3}{*}{1.} & \multicolumn{5}{|c|}{ Rasio Likuiditas } \\
\hline & \multirow{2}{*}{ Current Ratio } & $63,37 \%$ & $74,77 \%$ & $65,30 \%$ & \multirow{2}{*}{$\begin{array}{c}2 \mathrm{kali} \\
(200 \%)\end{array}$} \\
\hline & & Tidak Likuid & Tidak Likuid & Tidak Likuid & \\
\hline
\end{tabular}


ARTIKEL

\begin{tabular}{|c|c|c|c|c|c|}
\hline & \multirow{2}{*}{ Quick Ratio } & $44,27 \%$ & $50,89 \%$ & $46,70 \%$ & \multirow{2}{*}{$\begin{array}{l}1,5 \mathrm{kali} \\
(150 \%)\end{array}$} \\
\hline & & Tidak Likuid & Tidak Likuid & Tidak Likuid & \\
\hline & \multirow{2}{*}{ Cash Ratio } & $32,29 \%$ & $31,58 \%$ & $48,12 \%$ & \multirow{2}{*}{$50 \%$} \\
\hline & & Tidak Likuid & Tidak Likuid & Tidak Likuid & \\
\hline \multirow{9}{*}{2.} & \multicolumn{5}{|c|}{ Rasio Solvabilitas } \\
\hline & \multirow{2}{*}{$\begin{array}{c}\text { Debt to Assets } \\
\text { Ratio }\end{array}$} & $73 \%$ & $61 \%$ & $74 \%$ & \multirow{2}{*}{$35 \%$} \\
\hline & & Baik & Baik & Baik & \\
\hline & \multirow{2}{*}{$\begin{array}{c}\text { Debt to Equity } \\
\text { Ratio }\end{array}$} & $265 \%$ & $157 \%$ & $290 \%$ & \multirow{2}{*}{$90 \%$} \\
\hline & & Baik & Baik & Baik & \\
\hline & \multirow{2}{*}{$\begin{array}{c}\text { Long Term Debt to } \\
\text { Equity Ratio }\end{array}$} & $23 \%$ & $11 \%$ & $43 \%$ & \multirow{2}{*}{$\begin{array}{c}10 \mathrm{kali} \\
(1000 \%)\end{array}$} \\
\hline & & Kurang & Kurang & Kurang & \\
\hline & \multirow{2}{*}{$\begin{array}{l}\text { Time Interest } \\
\text { Earned Ratio }\end{array}$} & $74,39 \%$ & $113,16 \%$ & 44,08 & \multirow{2}{*}{$\begin{array}{c}10 \mathrm{kali} \\
(1000 \%)\end{array}$} \\
\hline & & Kurang & Kurang & Kurang & \\
\hline \multirow{11}{*}{3.} & \multicolumn{5}{|c|}{ Rasio Aktivitas } \\
\hline & \multirow{2}{*}{$\begin{array}{c}\text { Receivable } \\
\text { Turnover }\end{array}$} & 8,48 kali & 8,19 kali & 7,87 kali & \multirow{2}{*}{15 kali } \\
\hline & & Kurang & Kurang & Kurang & \\
\hline & \multirow{2}{*}{ Inventory Turnover } & 17,21 kali & 15,72 kali & 17,66 kali & \multirow[t]{2}{*}{20 kali } \\
\hline & & Kurang & Kurang & Kurang & \\
\hline & \multirow{2}{*}{$\begin{array}{c}\text { Working Capital } \\
\text { Turnover }\end{array}$} & 5,18 kali & 4,90 kali & 5,19 kali & \multirow{2}{*}{6 kali } \\
\hline & & Kurang & Kurang & Kurang & \\
\hline & \multirow{2}{*}{$\begin{array}{c}\text { Fixed Assets } \\
\text { Turnover }\end{array}$} & 3,75 kali & 3,44 kali & 3,55 kali & \multirow{2}{*}{5 kali } \\
\hline & & Kurang & Kurang & Kurang & \\
\hline & \multirow{2}{*}{$\begin{array}{c}\text { Total Assets } \\
\text { Turnover }\end{array}$} & 2,17 kali & 2,02 kali & 2,11 kali & \multirow{2}{*}{2 kali } \\
\hline & & Baik & Baik & Baik & \\
\hline \multirow{7}{*}{4} & \multicolumn{5}{|c|}{ Rasio Profitabilitas } \\
\hline & \multirow{2}{*}{ Net Profit Margin } & $17 \%$ & $22 \%$ & $17 \%$ & \multirow{2}{*}{$20 \%$} \\
\hline & & Kurang & Baik & Kurang & \\
\hline & \multirow{2}{*}{ Return on Equity } & $135 \%$ & $120 \%$ & $140 \%$ & $40 \%$ \\
\hline & & Baik & Baik & Baik & $40 \%$ \\
\hline & Return on & $37 \%$ & $47 \%$ & $36 \%$ & \\
\hline & & Baik & Baik & Baik & $30 \%$ \\
\hline
\end{tabular}

(Sumber : data diolah)

\section{Rasio Likuiditas}

Semakin tinggi rasio lancarnya, semakin likuid perusahaannya. Hasil Current Ratio atau Rasio Lancar yang diterima pada umumnya adalah 2 kali. Rasio Lancar sebesar 2 kali ini dianggap sebagai posisi nyaman dalam keuangan bagi kebanyakan perusahaan. Namun pada dasarnya, Rasio Lancar yang dapat diterima ini bervariasi antara satu industri dengan industri lainnya. Bagi kebanyakan industri, Rasio Lancar 
sebesar 2 kali sudah dianggap dapat diterima atau "Acceptable“.Nilai rendah pada Rasio Lancar (nilai yang kurang dari 1 kali) menunjukan bahwa perusahaan mungkin mengalami kesulitan untuk memenuhi kewajiban lancarnya. Namun Investor atau calon kreditur juga harus memperhatikan arus kas operasi perusahaan agar bisa lebih memahami tingkat likuiditas perusahaannya. Apabila Rasio Lancar Perusahaan rendah, para Investor atau calon kreditur dapat menilai kesehatan keuangan perusahaan yang bersangkutan dengan kondisi arus kas (cash flow) operasional pada perusahaan tersebut.

a. Current ratio

Current ratio jika dibandingkan dari laporan keuanganya 3 tahun kebelakang yaitu pada tahun 2017, 2018 dan 2019 masing - masing sebesar 63,37\%, 74,77\% dan 65,30\% atau dapat dikatakan masing - masing 0,6337 kali, 0,7477 kali dan 0,6530 kali. Dapat disimpulkan bahwa pada tahun 2017 - 2019 perhitungan hasil rasio lancar menunjukan kurang baik dimana rasio lancarnya kurang dari 200\% dan rata - rata hitungnya sebesar $67,81 \%$. Hal ini diakibatkan oleh persediaan yang tiap tahun selalu meningkat. Selain itu, piutang pihak ketiga, beban umum dan administrasi serta bunga pula mengalami kenaikan. Solusi yang bisa diambil PT Unilever adalah dengan meminimalkan biaya jangka pendek. Caranya dengan memperketat pengawasan dan mereview kembali kegiatan operasi.

\section{b. Quick Ratio}

Berdasarkan tabel 2 tersebut dapat diketahui nilai Quick Ratio PT Unilever Tbk dari tahun 2017 sampai tahun 2019 cenderung masih fluktuatif. Nilai ratio ini berarti pada tahun 2017 yaitu setiap Rp. 100 kewajiban dijamin dengan Rp. 44,27 aset lancar yang cepat diuangkan. Quick ratio pada tahun 2018 yaitu setiap Rp.100 kewajiban maka dijamin 50,89 aset lancar dan pada tahun 2019 yaitu setiap Rp.100 kewajiban akan dijamin 46,70 aset lancar yang cepat diuangkan. Fluktuasi yang terjadi diakibatkan oleh kenaikan hutang lancar juga diiringi dengan pertambahan aset lancar. Semakin besarnya aset lancar menunjukan semakin besar pula persediaan. Kondisi perusahaan dikatakan masih likuid namun kinerjanya dari tahun ke tahun cenderung masih belum bisa stabil. Untuk meningkatkan likuiditasnya, perusahaan dapat meningkatkan penggunaan dananya sehingga aktiva lancar akan semakin tinggi. Jadi, dapat disimpulkan bahwa PT Unilever dalam memenuhi kewajiban lancarnya belum dapat dikatakan baik.

c. Cash Ratio 
Sesuai data dalam tabel 2 tersebut, pada tahun 2017 - 2019 berturut - turut cash rationya sebesar $32,29 \%, 31,58 \%$ dan $48,12 \%$. Perhitungan rasio kasnya dinilai kurang baik karena dibawah kriteria yaitu kurang dari 50\%. Hal ini terjadi karena jumlah kas dan setara kas masih rendah jika dibandingkan hutang lancar yang akan jatuh tempo dalam kurun waktu satu tahun, Akibatnya, kas dan setara kas banyak digunakan untuk membiayai kewajiban lancar. Solusi yang mungkin PT Unilever dapat ambil adalah mencari alternative pendanaan lain untuk memenuhi kewajiban lancarnya. Kenaikan aktiva lancar dapat dilakukan antara lain dengan menjual aktiva tetap, mendapatkan tambahan modal sendiri dan mendapatkan tambahan hutang jangka panjang. Suhendro, D. (2018)

\section{Rasio Solvabilitas}

a. Debt to asset ratio

Dari hasil perhitungan tabel 2, debt to asset ratio pada tahun 2017 sebesar 0,73 atau $73 \%$, ini menunjukan bahwa setiap $73 \%$ pendanaan perusahaan dibiayai dengan hutang. Sedangkan ditahun 2018 mengalami penurunan sebesar 0,12 atau 12\% yaitu dari 0,73 menjadi 0,61 atau $61 \%$, ini berarti bahwa setiap $61 \%$ pendanaan perusahaan dibiayai oleh hutang. Namun pada tahun 2019 mengalami peningkatan kembali sebesar 0,13 atau $13 \%$ yaitu menjadi 0,74 atau $74 \%$. Ini menunjukkan $74 \%$ pendanaan perusahaan dibiayai dengan hutang. Kondisi diatas menunjukkan perusahaan dibiayai hampir 19 separuhnya hutang. Jadi dapat ditarik kesimpulan bahwa total hutang terhadap total asset dari tahun 2017 sampai tahun 2019 itu kurang baik. Hal ini akan membuat perusahaan semakin sulit untuk memperoleh pinjaman karena perusahaan dikhawatirkan tidak mampu menutupi utang yang dimilikinya. Maka jika perusahaan ingin menambah utang, perusahaan perlu menambah ekuitasnya.

\section{b. Debt to equity ratio}

Dari hasil perhitungan pada tabel 2 menunjukan bahwa Debt to equity ratio pada tahun 2017 sebesar 2,65 atau 265\%, ini berarti bahwa perusahaan dibiayai oleh hutang sebanyak 265\%. Kemudian pada tahun 2018 mengalami penurunan sebesar 1,07 atau $107 \%$ dari 2,65 atau $265 \%$ menjadi 1,58 atau $158 \%$, ini berarti bahwa perusahaan dibiayai oleh hutang sebanyak $158 \%$. Pada tahun 2019 debt to equity ratio kembali mengalami kenaikan menjadi 2,90 atau 290\% , ini berarti bahwa perusahaan dibiayai 
oleh hutang sebanyak 290\%. Jadi dapat disimpulkan bahwa kinerja keuangan perusahaan yang diukur dari debt to equity ratio tidak baik, namun jika dilihat dari laporan keuangannya hutang jangka pendek lebih besar daripada hutang jangka panjang, yang dimana hutang jangka pendek itu berupa hutang pajak penghasilan, hutang usaha yang apabila barang hasil produksi habis terjual hutang tersebut dapat segera dilunasi. Maka dapat dikatakan bahwa hutang tersebut tergolong sehat. Jadi kinerja keuangan PT Unilever dilihat dari debt to equity ratio itu dalam keadaan baik.

\section{c. Long Term Debt to Equity Ratio}

Long Term Debt to Equity Ratio mengalami fluktuasi dari tahun 2017 sampai tahun 2019. Pada tahun 2017 long term debt to equity nya sebesar 0,23 atau 23\%, hal ini menunjukkan bahwa setiap rupiah dari hutang jangka panjang perusahaan mampu dijamin dengan 0,23 rupiah dari modal sendiri atau dapat dikatakan bahwa kemampuan perusahaan dalam menutup seluruh hutang jangka panjangnya melalui modal sendiri adalah 23\%. Pada tahun 2018 terjadi penurunan long term debt to 2,65 1,58 2,9 2017 20182019 Perkembangan DER sebesar 0,12 atau 12\% dari 0,23 atau 23\% menjadi 0,11 atau $11 \%$, ini berarti bahwa setiap satu rupiah dari hutang jangka panjang perusahaan mampu dijamin dengan 0,11 rupiah dari modal sendiri atau dapat dikatakan bahwa kemampuan perusahaan dalam menutup seluruh hutang jangka panjangnya melalui modal sendiri adalah 11\%. Kemudian di tahun 2019 long term debt to equity mengalami kenaikan menjadi 0,43 atau 43\%, hal ini menunjukkan bahwa setiap rupiah dari hutang jangka panjang perusahaan mampu dijamin dengan 0,43 rupiah dari modal sendiri atau dapat dikatakan bahwa kemampuan perusahaan dalam menutup seluruh hutang jangka panjangnya melalui modal sendiri adalah $43 \%$.

\section{d. Times interest earned}

Dari hasil perhitungan tabel 2, times interest earned pada tahun 2017 adalah 73,39 kali, ini berarti pendapatan atau laba operasi perusahaan 73,39 kali lebih besar dari biaya beban bunga tahunannya. Kemudian mengalami kenaikan pada tahun 2018 menjadi 112,16 kali, ini berarti pendapatan atau laba operasi perusahaan 112,16 kali lebih besar dari biaya beban bunga tahunannya. Namun mengalami penurunan ditahun 2019 menjadi 43,01 kali, ini berarti pendapatan atau laba operasi perusahaan 43,01 kali lebih besar dari biaya beban bunga tahunannya. Jadi dapat ditarik kesimpulan bahwa time interest earned dari tahun 2017 sampai tahun 2019 cukup baik. 


\section{Rasio Aktivitas}

a. Receivable Turnover

Dari perhitungan pada tabel 2, didapatkan bahwa perputaran piutang yang terjadi di PT Unilever Indonesia di tahun 2017 yaitu sebesar 8,48 kali, di tahun 2018 adalah 8,19 kali dan untuk tahun 2019 adalah 7,87 kali. Penjualan kredit yang terjadi dari tahun ke tahun mengalami penurunan. Karena terjadi penurunan rasio perputaran piutang dari tahun 2017 ke tahun 2018 hingga tahun 2019 dapat dilihat bahwa penagihan piutang yang dilakukan manajemen dianggap tidak berhasil. Hasil dari perhitungan rasio di atas menunjukkan angka yang tidak terlalu besar yaitu dibawah $10 \mathrm{kali}$, hal ini menunjukkan bahwa modal kerja yang ditanamkan oleh Unilever Indonesia dalam piutang adalah tinggi dan tentunya kondisi ini bagi perusahaan tidak cukup baik. Hal ini dapat dilihat dari jumlah piutang yang terus meningkat dari tahun ke tahun dan penagihan piutang yang selalu mengalami penurunan.

Jika dihitung berdasarkan hari rata-rata penagihan piutang dilakukan dalam waktu 46 hari. Hal ini sama pada tahun 2017, 2018 dan 2019 dikarenakan perputaran piutang yang dibulatkan pada tiga tahun itu yaitu 8 kali. Setiap tahunnya tidak ada peningkatan maka berarti penagihan piutang pada ketiga tahun tersebut tidak mengalami peningkatan.

\section{b. Inventory Turnover}

Untuk tahun 2017 Rasio ini menunjukkan 17 kali sediaan barang dagangan diganti dalam satu tahun. Untuk berapa hari, rata-rata sediaan tersimpan dalam gudang pada tahun 2017 butuh waktu selama 21 hari bagi perusahaan Unilever untuk mengganti atau memperbaharui sediaan yang ada di gudangnya. Rasio ini menunjukkan 16 kali sediaan barang dagangan diganti dalam satu tahun. Karena hasil yang ditunjukkan oleh rasio perputaran sediaan ini cukup tinggi, ini berarti perusahaan Unilever Indonesia bekerja secara efiseien dan memiliki persediaan yang cukup baik, hal ini menunjukkan bahwa produk Unilever di pasar banyak digunakan dan dibutuhkan oleh konsumen dimana produk Unilever merupakan produk sehari-hari yang sering digunakan oleh masyarakat.

Untuk tahun 2019 Rasio ini menunjukkan 18 kali sediaan barang dagangan diganti dalam satu tahun. Jika dilihat dari hasil perhitungan tahun 2018 maka di tahun 2019 ini Unilever mengalami kenaikkan dalam perputaran sediaannya. Dapat dikatakan 
bahwa perputaran sediaan pada tahun 2019 lebih baik dibanding dengan tahun sebelumnnya ini juga berarti pada tiap tahunnya mengalami peningkatan. Semakin tinggi tingkat perputaran sediaan maka semakin tinggi eksistensi produk yang dijual, kepercayaan masyarakat terhadap produk yang dijual dan luasnya jangkauan penjualan juga menjadi salah satu faktor yang mendukung tinggingnya persediaan Unilever Indonesia. Begitu pula dengan waktu perputaran sediaan dalam hari semakin cepat yaitu hanya membutuhkan waktu 20 hari bagi perusahaan Unilever untuk memperbaharui persediaanya digudang.

\section{c. Working Capital Turn Over}

Untuk tahun $2017 W$ orking capital turn over adalah 5,18 kali atau dibulatkan 5 kali. Perputaran modal kerja tahun 2017 sebanyak 5,18 kali, artinya setiap Rp 1,00 modal kerja dapat menghasilkan Rp 5,18 penjualan.

Perputaran modal kerja tahun 2018 sebanyak 5,02 kali. Artinya setiap Rp 1,00 modal kerja dapat menghasilkan Rp 5 penjualan.

Perputaran modal kerja tahun 2019 sebanyak 5,03 kali. Artinya setiap Rp 1,00 modal kerja dapat menghasilkan Rp 5 penjualan. Hasil tersebut mengalami kenaikan dibanding tahun sebelumnya di tahun 2018 meskipun hanya 0,1.

Terlihat ada penurunan rasio perputaran modal kerja dari tahun 2017 ke 2018 yang tidak terlalu signifikan, lalu terjadi kenaikan rasio perputaran modal kerja dari tahun 2018 ke 2019, kenaikannya pun tidak terlalu tinggi. Hal ini menunjukkan ada kemajuan yang diperoleh manajemen tetapi tidak terlalu signifikan. Namun, jika ratarata industri untuk perputaran modal kerja diatas 5 kali, keadaan perusahaan, untuk tahun 2018 dan 2019, dinilai kurang baik karena berada di bawah rata-rata industri.

Artinya, dari rata-rata industri setiap Rp 1,00 modal kerja dapat menghasilkan Rp 5,18 penjualan di tahun 2017, Rp 5,02 penjualan di tahun 2018 dan Rp 5,03 penjualan di tahun 2019. Manajemen harus bekerja keras lagi untuk meningkatkan rasio perputaran modalnya hingga minimal mencapai atau sama dengan rata-rata industry. Sebab penilaian atau perputaran modal kerja ini menunjukkan seberapa efektif modal yang ditanamkan oleh perusahaan kepada aktiva sehingga menghasilkan penjualan.

\section{d. Fixed Assets Turn Over}

Perputaran aktiva tetap tahun 2017 sebanyak 3,94 kali. Artinya, setiap Rp 1,00 aktiva tetap dapat menghasilkan Rp 3,94 penjualan. Perputaran aktiva tetap tahun 2018 
sebanyak 3,94 kali. Artinya, setiap Rp 1,00 aktiva tetap dapat menghasilkan Rp 3,94 penjualan. Investasi dana yang dilakukan oleh perusahaan Unilever Indonesia terhadap aktiva tetapnya dapat menghasilkan 3,94 kali. Jika hasil rasio perputaran aktiva tetap ini semakin tinggi maka investasi kepada aktiva tetap bisa dikatakan berhasil dan menambah keuntungan serta meningkatkan nilai penjualan bersih. Akan tetapi jika dilihat dari rasio perputaran aktiva tetap dari tahun 2017 ke tahun 2018 tidak mengalamai penurunan ataupun kenaikan.

Kondisi perusahaan terlihat mengalami peningkatan karena terjadi kenaikan rasio perputaran aktiva tetap dari tahun 2018 ke tahun 2019 meskipun tidak terlalu signifikan. Ini menunjukkan bahwa perusahaan Unilever Indonesia tidak banyak merubah investasinya kepada aktiva tetap, tidak ada penambahan maupun pengurangan terhadap penanaman modal di aktiva tetap.

e. Total Assets Turn Over

Total assets turnover, juga terjadi penurunan di tiga tahun terakhir pada tahun 2017 sebesar 2,17 kali menjadi 2,14 kali di tahun 2018, dan 2,07 kali di tahun 2019. Perputaran total aktiva perusahaan tidak lebih besar dari hasil rasio perputaran aktiva tetap dan bahkan setiap tahunnya mengalami penurunan. Maka kemungkinan perusahaan menggunakan seluruh total aktiva kurang efisien dibandingakan dengan penggunaan aktiva tetapnya.

\section{Rasio Profitabilitas}

a. Net Profit Margin

Pada perhitungan NPM (Net Profit Margin) selama tiga tahun dari tahun 20172019 tersebut, GPM mengalami kenaikan sebesar 5\% dari 17\% menjadi 22\% di tahun 2018 dibandngkan tahun 2017, tetapi pada tahun 2019 GPM mengalami penurunan kembali sebesar $5 \%$ dari $22 \%$ menjadi $17 \%$ sehingga besarnya kembali sama dengan GPM 2017 yaitu 51\%. Ini artinya kinerja keuangan PT. Unilever Indonesia Tbk mengalami kinerja yang bagus antara 2017 menuju 2018 tetapi menurun di tahun 2019. Meskipun penjualannya selalu meningkat dari 2017-2019 tatpi laba bersih mengalami penurunan, dengan demikian rasio NPM PT. Unilever tersebut pun mengalami penurunan.

b. Return on equity 
Return on equity merupakan rasio yang sangat penting bagi pemilik perusahaan (The Common Stockholder), karena rasio ini menunjukkan tingkat kembalian yang dihasilkan oleh manajemen dari modal yang disediaan oleh pemilik perusahaan. ROE menunjukkan keuntungan yang akan dinikmati oleh pemilik saham. Nurfadillah, M. (2016)

Dari hasil perhitungan, maka dapat dilihat bahwa ROE mengalami penurunan 15\% pada tahun 2018 dari tahun 2017, tetapi mengalami kenaikan kembali sebesar $20 \%$ pada tahun 2019. ROE tahun 2017 sebesar 135\% hal ini berarti setiap Rp 1 modal menghasilkan RP 1,35 keuntungan. Pada tahun 2018 ROE PT. Unilever sebesar 120\% hal ini berarti Rp 1 modal menghasilkan keuntungan sebesar Rp 1,20 dan untuk ROE tahun 2019 yaitu 140\% ini berarti setiap Rp 1 modal menghasilkan keuntungan sebesar Rp 1,40. Dari hasil tersebut maka modal yang digunakan sudah cukup efisien untuk menghasilkan keuntungan perusahaan

\section{c. Return On Investment}

ROI berguna untuk mengukur kemampuan perusahaan secara keseluruhan dalam menghasilkan keuntungan terhadap jumlah aktiva secara keseluruhan yang tersedia pada perusahaan. Semakin tinggi rasio ini berarti semakin baik kondisi suatu perusahaan. ROI pada tahun 2018 mengalami kenaikan sebesar 10\% dari tahun 2018 yang awalnya $37 \%$ menjadi 47\%. Sedangkan pada tahun 2019 mengalami penurunan sebesar $11 \%$ dari tahun 2018 yaitu 47\% menjadi 36\%. Karena nilai ROI semakin besar menunjukan kondisi perushaaan yang semakin baik, maka dapat disimpulkan bahawa kondisi perusahaan sesuai ROI yang terbaik diantara 3 tahun tersebut yaitu pada tahun 2018 dan kondisi perusahaan kurang prima pada tahun 2019.

\section{KESIMPULAN}

Dalam rasio likuiditas dengan menggunakan alat analisis current ratio, quick ratio, cash raio dari tahun 2017-2019 menunjukan bahwa perusahaan dalam keadaan tidak likuid karena kurang dari standar rata - rata industri.

Dalam rasio solvabilitas di tahun 2017-2019 terjadi perbedaan kondisi antara Debt to Assets Ratio, Debt to Equity Ratio dan Long Term Debt to Equity Ratio, Time Interest Earned Ratio. Untuk DAR dan DER kondisinya baik. Sedangkan untuk long term debt to equity ratio dan time interest earning ratio.jauh dibawah standar rata - rata industri. 
Kemudian, untuk rasio aktivitas yang hanya Total Assets Turnover yang dikatakan baik karena melebihi rata-rata industri sedangkan untuk perhitungan komponen-komponen lain dari rasio aktivitas menunjukan hasil yang kurang baik karena semuanya dibawah rata - rata industri.

Dalam Rasio Profitabilitas yang diproyeksikan dengan NPM, ROA, dan ROI sebagai alat analisis menunjukan bawa PT. Unilever Indonesia Tbk di tahun 2017-2019 berada dalam kondisi baik, kecuali untuk rasio NPM yang nilainya masih berfluktuasi. Oleh karena itu, dapat diambil kesimpulan bahwa komponen - komponen perhitungan dari setiap rasio yang berpengaruh signifikan terhadap kinerja perusahaan dari rasio solvabilitas adalah Debt to Assets Ratio dan Debt to Equity Ratio. Pada rasio profitabilitas yang berpengaruh adalah ROA dan ROI.

\section{DAFTAR PUSTAKA}

Kasmir, 2017. Analisis Laporan Keuangan. Jakarta : Raja Grafindo Persada.

Martono dan Harjito, D, Agus. (2005). Manajemen Keuangan. Yogyakarta: Ekonisia. Prihadi, T. (2019).

Analisis Laporan Keuangan - Konsep dan Aplikasi. Jakarta: PT Gramedia Pustaka Utama

Yusra, I. (2016). Kemampuan Rasio Likuiditas Dan Solvabilitas Dalam Memprediksi Laba Perusahaan Perusahaan: Studi Empiris Pada PerusahaanTelekomunikasi Yang Terdaftar Di Bursa Efek Indonesia. Jurnal Benefita, 1(1).

Nurfadillah, M. (2016). Analisis Pengaruh Earning Per Share, Debt to Equity Ratio Dan Return On Equity Terhadap Harga Saham PT Unilever Indonesia Tbk. Jurnal Manajemen Dan Akuntansi, 12(1).

Azizah, A. (2015). Analisis Kinerja Keuangan Perusahaan (Perbandingan Penggunaan Analisis Rasio Keuangan Dan Du Pont System)(Studi Pada PT. Unilever Indonesia, Tbk Dan Anak Perusahaan Yang Terdaftar Di Bursa Efek Indonesia Periode 2007-2013) (Doctoral dissertation, Brawijaya University).

Suhendro, D. (2018). Analisis penilaian kinerja keuangan perusahaan menggunakan rasio keuangan pada pt unilever indonesia tbk yang terdaftar di bursa efek indonesia (bei). At-Tawassuth: Jurnal Ekonomi Islam, 3(1), 23-47.

Mas'amah, F. A. T. M. A. T. U. L., Salim, M. A., \& Priyono, A. A. (2019). Pengaruh Rasio Profitabilitas Terhadap Nilai Perusahaan (Studi Empiris Perusahaan 
Manufaktur Sub Sektor Makanan Dan Minuman Yang Terdaftar Di BEI Periode Tahun 2015-2017). Jurnal Ilmiah Riset Manajemen, 8(10).

Dewa, A. P., \& Sitohang, S. (2015). Analisis kinerja keuangan PT Indofood Sukses Makmur TBK di bursa efek indonesia. Jurnal Ilmu dan Riset Manajemen, 4(3), 115.

Rahmayeli, D. S., \& Marlius, D. (2017). Analisis Kinerja Keuangan Pada PT. Bank Perkreditan Rakyat (BPR) Batang Kapas Pesisir Selatan.

Arifin, I. Z., \& Marlius, D. (2017). Analisis Kinerja Keuangan PT. Pegadaian Cabang Ulak Karang.

Lithfiyah, E., Irwansyah, I., \& Fitria, Y. (2019). Analisis rasio keuangan pt telekomunikasi indonesia tbk. AKUNTABEL, 16(2),

Julia, H. Pengaruh Earning Per Share, Return On Assset, Net Profit Margin, Dan Dividen Payout Ratio Terhadap Nilai Perusahaan Pada Perusahaan LQ45 Yang Terdaftar Di Bursa Efek Indonesia Tahun 2015-2017. Pengaruh Earning Per Share, Return On Assset, Net Profit Margin, Dan Dividen Payout Ratio Terhadap Nilai Perusahaan Pada Perusahaan LQ45 Yang Terdaftar Di Bursa Efek Indonesia Tahun 2015-2017.

www.unilever.co.id

www.idx.co.id

www.finance.yahoo.com 